\title{
Elizabethkingia anophelis sp. nov., isolated from the midgut of the mosquito Anopheles gambiae
}

\author{
Correspondence \\ Peter Kämpfer \\ peter.kaempfer@umwelt.uni- \\ giessen.de
}

\author{
Peter Kämpfer, ${ }^{1}$ Holly Matthews, ${ }^{2}$ Stefanie P. Glaeser, ${ }^{3}$ Karin Martin, ${ }^{4}$ \\ Nicole Lodders ${ }^{1}$ and Ingrid Faye ${ }^{2}$ \\ ${ }^{1}$ Institut für Angewandte Mikrobiologie, Universität Giessen, Giessen, Germany \\ ${ }^{2}$ Department of Genetics, Microbiology and Toxicology, Stockholm University, \\ S-106 91 Stockholm, Sweden \\ ${ }^{3}$ Institut für Mikro- und Molekularbiologie, Universität Giessen, Giessen, Germany \\ ${ }^{4}$ Leibniz-Institut für Naturstoff-Forschung und Infektionsbiologie eV, Hans-Knöll-Institut, Jena, \\ Germany
}

\begin{abstract}
The taxonomic position, growth characteristics and antibiotic resistance properties of a slightly yellow-pigmented bacterial strain, designated $\mathrm{R} 26^{\top}$, isolated from the midgut of the mosquito Anopheles gambiae, were studied. The isolate produced rod-shaped cells, which stained Gram-negative. The bacterium had two growth optima at $30-31{ }^{\circ} \mathrm{C}$ and $37{ }^{\circ} \mathrm{C}$. Strain R26 demonstrated natural antibiotic resistance to ampicillin, chloramphenicol, kanamycin, streptomycin and tetracycline. 16S rRNA gene sequence analysis revealed that the isolate showed $98.6 \%$ sequence similarity to that of Elizabethkingia meningoseptica ATCC $13253^{\top}$ and $98.2 \%$ similarity to that of Elizabethkingia miricola GTC $862^{\top}$. The major fatty acids of strain $\mathrm{R}^{2} 6^{\top}$ were iso- $\mathrm{C}_{15: 0}$, iso- $\mathrm{C}_{17: 0} 3-\mathrm{OH}$ and summed feature 4 (iso- $\mathrm{C}_{15: 0} 2-\mathrm{OH}$ and/or $\mathrm{C}_{16: 1} \omega 7 \mathrm{c} / \mathrm{t}$ ). Strain $\mathrm{R}_{26}{ }^{\top}$ contained only menaquinone MK-6 and showed a complex polar lipid profile consisting of diphosphatidylglycerol, phosphatidylinositol, an unknown phospholipid and unknown polar lipids and glycolipids. DNA-DNA hybridization experiments with E. meningoseptica CCUG $214^{\top}$ $\left(=\right.$ ATCC $\left.13253^{\top}\right)$ and E. miricola KCTC $12492^{\top}\left(=\right.$ GTC $\left.862^{\top}\right)$ gave relatedness values of $34.5 \%$ (reciprocal $41.5 \%$ ) and $35.0 \%$ (reciprocal $25.7 \%$ ), respectively. DNA-DNA hybridization results and some differentiating biochemical properties indicate that strain $\mathrm{R}^{2} 6^{\top}$ represents a novel species, for which the name Elizabethkingia anophelis sp. nov. is proposed. The type strain is $\mathrm{R}^{2} 6^{\top}$ (=CCUG $60038^{\top}=\mathrm{CCM} 7804^{\top}$ ).
\end{abstract}

The genus Elizabethkingia was proposed by Kim et al. (2005) for the two species Elizabethkingia meningoseptica and Elizabethkingia miricola mainly on the basis of $16 \mathrm{~S}$ rRNA gene sequence similarity studies. Strains of these species represent a separate lineage from the type strains of the Chryseobacterium-Bergeyella-Riemerella branch within the family Flavobacteriaceae (90.7-93.9\% similarities), which is also supported by phenotypic differences. Since 2005, no further species of this genus have been proposed. Representatives of the genus Elizabethkingia can be found in a wide variety of samples, including clinical sources (Bernardet et al., 2006).

During the characterization of organisms from the midgut of Anopheles gambiae G3 originating from McCarthy Island,

Abbreviations: pNA, $p$-nitroanilide; $\mathrm{pNP}, p$-nitrophenyl; RAPD, randomly amplified polymorphic DNA; rep-PCR, repetitive extragenic palindromicPCR.

The GenBank/EMBL/DDBJ accession number for the $16 \mathrm{~S}$ rRNA gene sequence of strain $\mathrm{R}^{2} 6^{\top}$ is EF426434.
The Gambia, a bacterial isolate was commonly recovered on Luria-Bertani (LB) agar containing ampicillin (100 $\left.\mu \mathrm{g} \mathrm{ml}^{-1}\right)$ at $37^{\circ} \mathrm{C}$ (Lindh et al., 2008) and was subsequently deposited by Dr William Collins at the Malaria Research Reference Resource Centre managed by the ATCC (MR4/ATCC). This bacterium was identified in 40 adults and two pupae of A. gambiae. Initial $16 \mathrm{~S}$ rRNA gene sequencing and BLAST comparison showed that the isolate was most closely related to Elizabethkingia meningoseptica strains (GenBank accession nos EF426425-EF426434; Lindh et al., 2008). Several other laboratories have since reported the isolation of bacteria from the gut of mosquitoes that share 16S rRNA gene sequence similarities of 99-100\% with Elizabethkingia meningoseptica (Dong et al., 2009; Kajla et al., 2010). The aim of the present study was to look further at this mosquito inhabitant. One of our isolates, originally designated strain $\mathrm{R} 26^{\mathrm{T}}$ (Lindh et al., 2008), was selected for further study.

Isolate $\mathrm{R} 26^{\mathrm{T}}$ was maintained and subcultivated on nutrient agar (NA; Oxoid) at $30{ }^{\circ} \mathrm{C}$ for $48 \mathrm{~h}$ and subsequently 
analysed for its $16 \mathrm{~S}$ rRNA gene sequence, fatty acid methyl ester composition of the whole cell hydrolysate, quinone and polar lipid patterns, further phenotypic characteristics, and DNA-DNA relatedness to those species most closely related on the basis of $16 \mathrm{~S}$ rRNA gene sequence similarities. The type strains of E. meningoseptica CCUG $214^{\mathrm{T}}$ and E. miricola $\mathrm{KCTC} 12492^{\mathrm{T}}$ were studied in parallel.

Growth was investigated at 4, 11, 15, 20,25, 30, 37, 45 and $50{ }^{\circ} \mathrm{C}$ in tryptone soy broth (TSB; Oxoid). Growth optima were determined between 27 and $41{ }^{\circ} \mathrm{C}$ in LB medium while shaking at 180 r.p.m. Oxidase activity was tested using the Oxidase reagent (bioMérieux) according to the instructions provided.

Physiological characterization and additional biochemical tests were performed as described previously (Kämpfer et al., 1991, 2010). In addition, the following biochemical tests were performed: the production of hydrogen sulfide using lead acetate paper and triple-sugar-iron methods; the indole reaction with Ehrlich's and Kovacs' reagents; the activities of arginine dihydrolase, lysine decarboxylase, ornithine decarboxylase, DNase (Oxoid CM321, supplemented with $0.01 \%$ toluidine blue), $\beta$-galactosidase (ONPG) and urease (on Christensen's urea agar); hydrolysis of casein, gelatin (plate method), starch and tyrosine; citrate utilization; and catalase activity (Smibert \& Krieg, 1994). Anaerobic growth was tested in TSB-containing tubes sealed with sterile paraffin oil. All phenotypic tests were performed with strain $\mathrm{R}^{2} 6^{\mathrm{T}}$ and the type strains of E. meningoseptica and $E$. miricola; all three strains were maintained and grown under the same conditions.

Table 1. Characteristics differentiating strain $R 26^{\top}$ from species of the genus Elizabethkingia

Strains: $1, \mathrm{R} 26^{\mathrm{T}} ; 2$, E. meningoseptica CCUG $214^{\mathrm{T}} ; 3$, E. miricola KCTC $12492^{\mathrm{T}}$. +, Positive; V, variable; - , negative. All data are from this study, except data in parentheses, which are from Kim et al. (2005). Acid production from arabinose, raffinose, salicin, sucrose and xylose is negative for all strains tested. Acid production from glucose, lactose, maltose, mannitol and trehalose is positive for all strains tested. Only characteristics that differ between the three strains are shown.

\begin{tabular}{|c|c|c|c|}
\hline Characteristics & 1 & $2^{\star}$ & 3 \\
\hline Citrate utilization & - & $-(\mathrm{v})$ & $+(+)$ \\
\hline \multicolumn{4}{|l|}{ Acid production from: } \\
\hline Cellobiose & + & $-(-)$ & $-(-)$ \\
\hline Melibiose & - & + & - \\
\hline Growth on MacConkey agar & - & $+(\mathrm{v})$ & $+(+)$ \\
\hline Urea hydrolysis & - & $-(-)$ & $+(+)$ \\
\hline
\end{tabular}

*Bernardet et al. (2006) reported that, for E. meningoseptica, acid production from cellobiose was found to vary between references and growth on MacConkey agar was strain-dependent. These findings were based on the study of a large number of E. meningoseptica strains.
Since Elizabethkingia meningoseptica is known to be resistant to several antibiotics and a putative pathogen that can cause meningitis in neonates (Bernardet et al., 2006), the isolate was investigated for antibiotic resistance. MICs were tested in LB medium. The isolate was also tested for haemolytic activity on blood agar plates.

Cellular fatty acid analysis was performed for strain $\mathrm{R} 26^{\mathrm{T}}$ and the type strains of E. meningoseptica and E. miricola after extraction of whole cell hydrolysates according to Kämpfer \& Kroppenstedt (1996). Menaquinones were extracted and analysed as described by Collins et al. (1977) and Groth et al. (1996). Polar lipids extracted by the method of Minnikin et al. (1979) were identified by two-dimensional TLC as described by Collins \& Jones (1980). For these analyses, strains were grown on tryptic soy agar (TSA; Difco) at $28{ }^{\circ} \mathrm{C}$ for $48 \mathrm{~h}$.

The 16S rRNA gene was analysed as described by Kämpfer et al. (2003). DNA extraction was carried out using the GenElute Plant Genomic DNA kit (Sigma-Aldrich) according to the manufacturer's instructions. The $16 \mathrm{~S}$ rRNA gene was PCR-amplified using the primer pair $27 \mathrm{~F}$ and $1492 \mathrm{R}$ (Lane, 1991) and the following cycle conditions: $95{ }^{\circ} \mathrm{C}$ for 3 min, 28 cycles of $94{ }^{\circ} \mathrm{C}$ for $1 \mathrm{~min}, 57.3{ }^{\circ} \mathrm{C}$ for $45 \mathrm{~s}, 72{ }^{\circ} \mathrm{C}$ for $2 \mathrm{~min}$, and a final step of $72{ }^{\circ} \mathrm{C}$ for $15 \mathrm{~min}$. The PCR product was purified with the QIAquick PCR purification kit

Table 2. Cellular fatty acids (\%) of strain $R 26^{\top}$ and species of the genus Elizabethkingia

Strains: $1, \mathrm{R}^{2} 6^{\mathrm{T}}$; 2, E. meningoseptica CCUG $214^{\mathrm{T}}$; 3, E. miricola KCTC $12492^{\mathrm{T}}$. All data are from this study, except data in parentheses, which are from Kim et al. (2005). Fatty acids (\%) are listed using standard abbreviations (no. of carbon atoms: no. of double bonds). $\operatorname{tr}$, Trace ( $<1.0 \%)$; ECL, equivalent chain-length (i.e. the identity of the fatty acid is unknown). Fatty acids amounting to $<1 \%$ total fatty acids in all three strains are not shown.

\begin{tabular}{|lrcc|}
\hline Fatty acid & $\mathbf{1}$ & $\mathbf{2}^{*}$ & $\mathbf{3} \dagger$ \\
\hline iso- $\mathrm{C}_{13: 0}$ & 1.8 & $2.8(1.3 \pm 0.3)$ & $2.1(2.0 \pm 0.5)$ \\
$\mathrm{ECL} 13.566$ & 6.8 & $6.3(1.9 \pm 0.3)$ & $4.9(1.5 \pm 0.2)$ \\
iso- $_{15: 0}$ & 45.8 & $40.8(43.9 \pm 2.0)$ & $44.7(46.4 \pm 2.2)$ \\
iso- $_{15: 0} 3-\mathrm{OH}$ & 2.9 & $3.1(2.8 \pm 0.3)$ & $3.6(3.0 \pm 0.6)$ \\
anteiso- $_{15: 0}$ & 1.8 & $3.9(1.1 \pm 0.8)$ & $1.5(1.0 \pm 0.6)$ \\
$\mathrm{C}_{16: 0}$ & $\operatorname{tr}$ & $1.8(\operatorname{tr})$ & $1.1(1.2 \pm 0.1)$ \\
$\mathrm{C}_{16: 0} 3-\mathrm{OH}$ & 2.1 & $3.4(2.6 \pm 0.4)$ & $2.4(3.0 \pm 0.6)$ \\
iso- $\mathrm{C}_{16: 0} 3-\mathrm{OH}$ & $\operatorname{tr}$ & $1.3(\operatorname{tr})$ & $\operatorname{tr}(\operatorname{tr})$ \\
ECL 16.580 & 1.2 & $1.1(1.6 \pm 0.1)$ & $1.4(1.3 \pm 0.6)$ \\
iso- $\mathrm{C}_{17: 0} 3-\mathrm{OH}$ & 12.8 & $12.4(14.6 \pm 1.0)$ & $14.6(15.3 \pm 0.2)$ \\
iso- $\mathrm{C}_{17: 1} \omega 9 c$ & 4.2 & $4.0(7.8 \pm 1.3)$ & $4.5(6.6 \pm 0.2)$ \\
Summed feature $4 \ddagger$ & 15.6 & $14.2(19.6 \pm 1.0)$ & $15.7(17.0 \pm 1.3)$ \\
& & & \\
\hline
\end{tabular}

${ }^{\star}$ Data in parentheses are means $\pm \mathrm{SD}$ derived from results for five strains.

$\dagger$ Data in parentheses are means $\underline{ \pm S D}$ derived from results for two strains.

$\ddagger$ Summed feature 4 comprises iso- $\mathrm{C}_{15: 0} 2-\mathrm{OH}$ and/or $\mathrm{C}_{16: 1} \omega 7 \mathrm{c} / \mathrm{t}$. 
(Qiagen) according to the manufacturer's instructions and was sequenced with standard sequencing primers for the $16 \mathrm{~S}$ rRNA gene (sequence length $1475 \mathrm{bp}$ ). Phylogenetic analysis was performed using the ARB software package (December 2007 version; Ludwig et al., 2004) and the corresponding SILVA SSURef 95 database (July 2008 release; Pruesse et al., 2007). Trees were reconstructed using the maximumlikelihood method with fastDNAml (Olsen et al., 1994) without filters. The almost complete $16 \mathrm{~S}$ rRNA gene sequences (1312 bp) of the three strains were compared by distance calculations (pairwise distances) using the ARB software package (December 2007 version; Ludwig et al., 2004).

DNA-DNA hybridization experiments were performed between strain $\mathrm{R} 26^{\mathrm{T}}$ and the type strains of the two species of the genus Elizabethkingia according to the method of Ziemke et al. (1998) except that, for nick translation, $2 \mu \mathrm{g}$ DNA was labelled during $3 \mathrm{~h}$ of incubation at $15{ }^{\circ} \mathrm{C}$.

Four repetitive extragenic palindromic (rep)-PCRs [ERIC-, REP-, BOX- and (GTG) ${ }_{5}$-PCR (Versalovic et al., 1994)] and randomly amplified polymorphic DNA (RAPD)-PCR (Welsh \& McClelland 1990; Williams et al., 1990) were tested to compare strain $\mathrm{R} 26^{\mathrm{T}}$ and the type strains of both species of the genus Elizabethkingia. ERIC- and rep-PCR could not be used because amplification products were not observed for all strains. All PCRs were performed in a total volume of $10 \mu \mathrm{l}$ including $40 \mathrm{ng}$ genomic DNA, $1 \times$ Taq buffer with $\left(\mathrm{NH}_{4}\right)_{2} \mathrm{SO}_{4}$ (Fermentas), $1.5 \mathrm{mM} \mathrm{MgCl}_{2}$, $1.25 \mathrm{mM}$ dNTPs, $2 \mu \mathrm{M}$ of each primer, $0.4 \mu \mathrm{g}$ bovine serum albumin $\mu \mathrm{l}^{-1}$ and $0.8 \mathrm{U}$ DreamTaq DNA polymerase (Fermentas). rep-PCRs were performed with primers ERIC1R and ERIC2, REP-1R-I and REP-2-I BOXA1R, and $(\mathrm{GTG})_{5}$ (Versalovic et al., 1994). PCR conditions for BOXand (GTG) $)_{5}$-PCR were as follows: 3 min at $95{ }^{\circ} \mathrm{C}$, followed by 30 cycles of $30 \mathrm{~s}$ at $94{ }^{\circ} \mathrm{C}, 1 \mathrm{~min}$ at $53{ }^{\circ} \mathrm{C}$, and $8 \mathrm{~min}$ (BOX-PCR) or $3 \mathrm{~min}\left[(\mathrm{GTG})_{5}-\mathrm{PCR}\right]$ at $70{ }^{\circ} \mathrm{C}$, and finished with $8 \mathrm{~min}$ at $70{ }^{\circ} \mathrm{C}$. RAPD-PCR analysis was performed with primer A and PCR conditions as described by Ziemke et al. (1997). PCR products were separated on $1.5 \%$ agarose gels in $1 \times$ Tris-borate-EDTA buffer for $2.5 \mathrm{~h}$ at $2.7 \mathrm{~V} \mathrm{~cm}^{-1}$, stained with ethidium bromide and documented using a Fluor-S MultiImager (Bio-Rad).

The isolate formed visible, slightly yellowish colonies with a diameter of $\sim 2 \mathrm{~mm}$ on NA within $48 \mathrm{~h}$ at $30{ }^{\circ} \mathrm{C}$. The Gram reaction was negative as tested by the modified Hucker method according to Gerhardt et al. (1994). No motility was observed under the light microscope on cells grown for 3 days in nutrient broth (Oxoid) at $30{ }^{\circ} \mathrm{C}$. The growth optimum in LB medium was observed from 31 to $37^{\circ} \mathrm{C}$ with a doubling time of $42 \mathrm{~min}$. No growth was observed below $10{ }^{\circ} \mathrm{C}$ or above $37^{\circ} \mathrm{C}$. The flexirubin test $(\mathrm{KOH}$ method; Reichenbach, 1992) was negative. Oxidase activity was positive. Good growth was observed on NA, R2A agar and TSA, but no growth was visible on MacConkey agar (Oxoid).

Isolate $\mathrm{R} 26^{\mathrm{T}}$ did not utilize the carbon sources tested, which is similar to the type strains of both species of the genus Elizabethkingia, but was positive for hydrolysis of some chromogenic substrates. Differential characteristics of the three strains are summarized in Table 1.

The fatty acid profile was similar to those found in other species of the genus Elizabethkingia, with the most abundant fatty acids being iso- $\mathrm{C}_{15: 0}$, iso- $\mathrm{C}_{17: 0} 3-\mathrm{OH}$ and summed feature 4 (iso- $\mathrm{C}_{15: 0} 2-\mathrm{OH}$ and/or $\mathrm{C}_{16: 1} \omega 7 c / t$ ). The complete fatty acid pattern of strain $\mathrm{R} 26^{\mathrm{T}}$ is shown in Table 2 along with those of the type strains of the two species of the genus Elizabethkingia.

Strain $\mathrm{R} 26^{\mathrm{T}}$ showed a complex polar lipid profile consisting of diphosphatidylglycerol, phosphatidylinositol, one
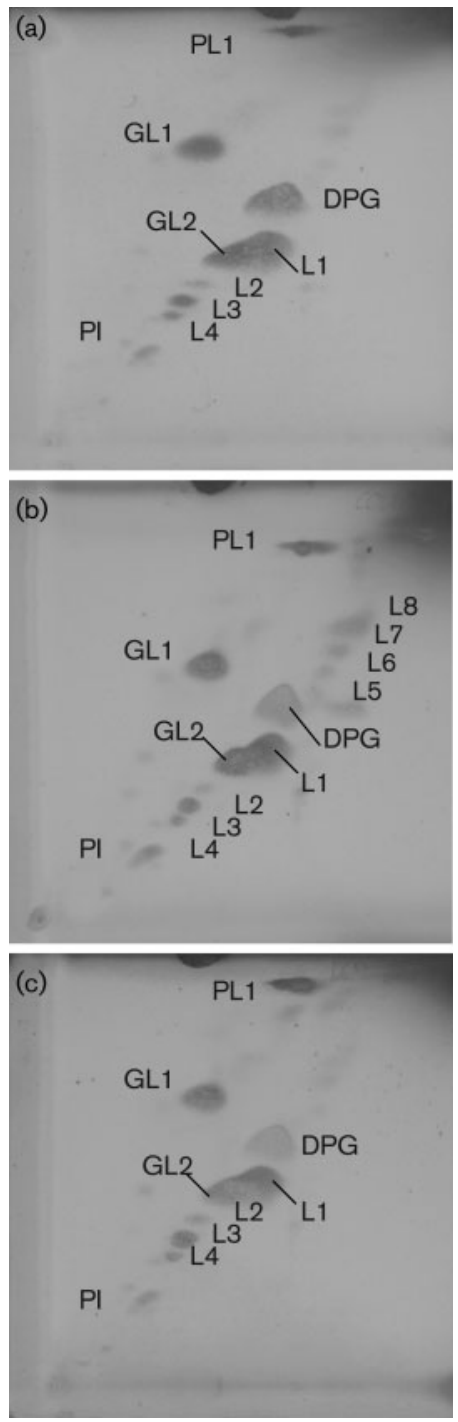

Fig. 1. Total polar lipid profiles, obtained after staining with molybdenum blue, of strain $\mathrm{R}^{2} 6^{\mathrm{T}}$ (a), E. meningoseptica CCUG $214^{\top}$ (b) and E. miricola KCTC $12492^{\top}$ (c). DPG, Diphosphatidylglycerol, PI, phosphatidylinositol, PL1, unidentified phospholipid; L1-L8, unidentified polar lipids; GL1, GL2, unidentified glycolipids. 


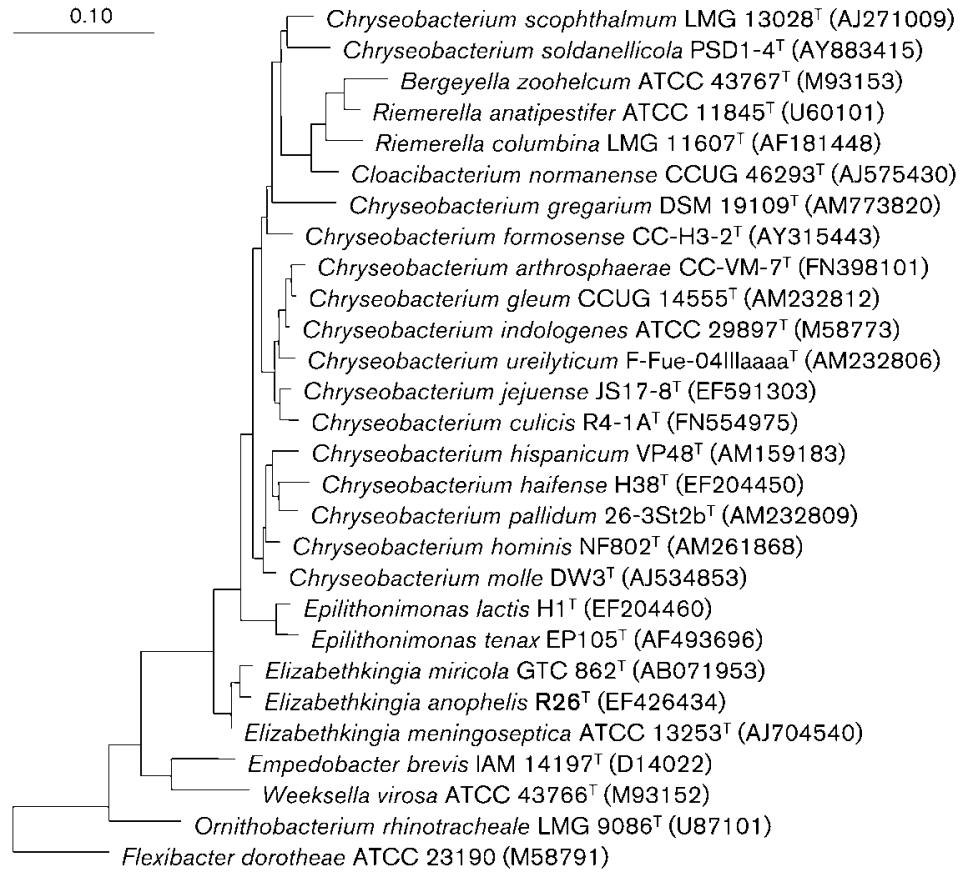

Fig. 2. Phylogenetic analysis of species most closely related to strain $\mathrm{R}^{2} 6^{\top}$ based on $16 \mathrm{~S}$ rRNA gene sequences available from EMBL (accession nos are given in parentheses). Tree building was performed with the maximumlikelihood algorithm without filters for 53 sequences. For clarity, only a subset of sequences (those with $93.3 \%$ or higher sequence similarity to strain $\mathrm{R}_{26} 6^{\mathrm{T}}$ ) are shown for the genus Chryseobacterium. Flexithrix dorotheae ATCC 23190 was used as an outgroup. Bar, 0.10 substitutions per nucleotide position. unidentified phospholipid, four unidentified polar lipids and two glycolipids. E. meningoseptica CCUG $214^{\mathrm{T}}$ contained four additional polar lipids with higher relative front values than diphosphatidylglycerol (L5-L8), only traces of which were detectable in strain $\mathrm{R} 26^{\mathrm{T}}$ and E. miricola KCTC $12492^{\mathrm{T}}$ (Fig. 1). The only menaquinone of strain $\mathrm{R} 26^{\mathrm{T}}$ was

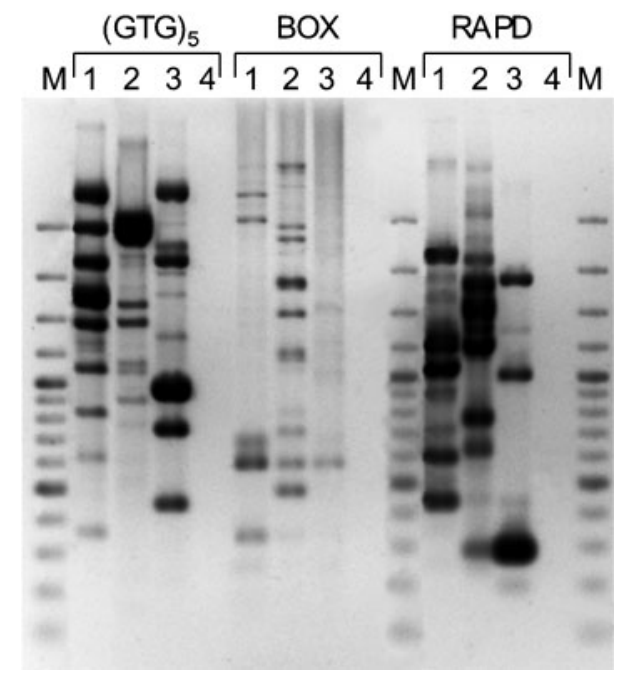

Fig. 3. Genomic fingerprint patterns generated by (GTG) $5_{5}$, BOXand RAPD-PCR; ethidium bromide-stained fingerprint patterns separated on agarose gels are shown. Lanes: 1 , strain $\mathrm{R}_{2}{ }^{\mathrm{T}}$; 2, E. meningoseptica CCUG $214^{\top}$; 3, E. miricola KCTC $12492^{\top}$; 4, no template control; M, GeneRuler 100 bp Plus DNA ladder (Fermentas).
MK-6 (99\%); this menaquinone was also detected in $E$. meningoseptica CCUG $214^{\mathrm{T}}$ and E. miricola KCTC $12492^{\mathrm{T}}$.

A maximum-likelihood tree for the $16 \mathrm{~S}$ rRNA gene is shown in Fig. 2. Strain R $26^{\mathrm{T}}$ formed a separate cluster with the type strains of species of the genus Elizabethkingia. Further calculations confirmed that the closest relatives of the isolate were E. meningoseptica ATCC $13253^{\mathrm{T}}$ and E. miricola GTC $862^{\mathrm{T}}$, which showed sequence similarities of 98.6 and $98.2 \%$, respectively, to the isolate. DNA-DNA hybridizations of strain $\mathrm{R} 26^{\mathrm{T}}$ with E. meningoseptica CCUG $214^{\mathrm{T}}$ and E. miricola KCTC $12492^{\mathrm{T}}$ gave similarities of $34.5 \%$ (reciprocal $41.5 \%$ ) and $35.0 \%$ (reciprocal $25.7 \%$ ), respectively. Genomic fingerprints generated by BOX-, $(\mathrm{GTG})_{5^{-}}$and RAPD-PCR showed clear differences between strain R26 ${ }^{\mathrm{T}}$, E. meningoseptica CCUG $214^{\mathrm{T}}$ and E. miricola KCTC $12492^{\mathrm{T}}$ (Fig. 3).

Although the chemotaxonomic data demonstrate a high similarity between strain $\mathrm{R} 26^{\mathrm{T}}$ and the type strains of both species of the genus Elizabethkingia, hybridization experiments, genomic fingerprint analysis and physiological data allow a clear separation of strain $\mathrm{R} 26^{\mathrm{T}}$ from the other species. On the basis of the reported results, a novel species, Elizabethkingia anophelis sp. nov., is proposed to accommodate strain $\mathrm{R} 26^{\mathrm{T}}$.

\section{Description of Elizabethkingia anophelis sp. nov.}

Elizabethkingia anophelis (a.no.phe'lis. N.L. gen. n. anophelis of/from a mosquito of the genus Anopheles, as the type strain was isolated from the midgut of Anopheles gambiae).

Cells are aerobic Gram-reaction-negative, non-motile, non-spore-forming rods, approximately $1 \mu \mathrm{m}$ in width 
and $2 \mu \mathrm{m}$ in length. Oxidase- and catalase-positive. Good growth occurs after $48 \mathrm{~h}$ on NA, R2A agar and TSA (all Oxoid) at $11-36{ }^{\circ} \mathrm{C}$. No growth occurs on MacConkey agar (Oxoid) at $28{ }^{\circ} \mathrm{C}$. Unable to grow at temperatures below $10{ }^{\circ} \mathrm{C}$ or above $37{ }^{\circ} \mathrm{C}$. Two growth optima are detected on LB medium: $30-31{ }^{\circ} \mathrm{C}$ with a doubling time of $50 \mathrm{~min}$; and $37{ }^{\circ} \mathrm{C}$ with a doubling time of $42 \mathrm{~min}$. Colonies on NA are smooth, yellowish, circular, translucent and shiny with entire edges. The non-diffusible and non-fluorescent yellow pigment is not of the flexirubin-type ( $\mathrm{KOH}$ test-negative). Resistant to a number of antibiotics; MICs in LB medium are $>400 \mu \mathrm{g} \mathrm{ml}^{-1}$ for ampicillin, $>250 \mu \mathrm{g} \mathrm{ml}^{-1}$ for kanamycin, $>250 \mu \mathrm{g} \mathrm{ml}^{-1}$ for streptomycin, $>30 \mu \mathrm{g} \mathrm{ml}^{-1}$ for chloramphenicol and $>10 \mu \mathrm{g} \mathrm{ml}^{-1}$ for tetracycline. Tests for haemolytic activity on blood agar plates show no lytic zones around the colonies. Acid is produced from D-glucose, lactose (weak), D-mannitol, maltose, L-rhamnose, sucrose, trehalose and cellobiose (weak). No acid is produced from adonitol, L-arabinose, D-arabitol, dulcitol, erythritol, iinositol, melibiose, methyl $\alpha$-D-glucoside, raffinose, salicin, D-sorbitol or D-xylose. Aesculin hydrolysis, indole production from tryptophan and $\beta$-galactosidase activity (ONPG) are positive. Urease activity, hydrolysis of casein, gelatin, starch, DNA and tyrosine, hydrogen sulfide production, activity of arginine dihydrolase, lysine decarboxylase and ornithine decarboxylase, and utilization of malonate are negative. The following compounds are not utilized as sole sources of carbon: $\mathrm{N}$-acetyl-D-galactosamine, $\mathrm{N}$-acetyl-Dglucosamine, L-arabinose, L-arbutin, cellobiose, D-fructose, D-glucose, maltose, D-galactose, gluconate, glycerol, Dmannose, D-mannitol, maltitol, $\alpha$-melibiose, L-rhamnose, D-ribose, sucrose, salicin, trehalose, D-xylose, adonitol, inositol, D-sorbitol, putrescine, acetate, propionate, cisaconitate, trans-aconitate, 4 -aminobutyrate, adipate, azelate, fumarate, glutarate, DL-3-hydroxybutyrate, itaconate, DLlactate, 2-oxoglutarate, pyruvate, suberate, citrate, mesaconate, L-alanine, $\beta$-alanine, L-ornithine, L-phenylalanine, L-serine, L-aspartate, L-histidine, L-leucine, L-proline, Ltryptophan, 3-hydroxybenzoate, 4-hydroxybenzoate and phenylacetate. The chromogenic substrates $p$-nitrophenyl (pNP)- $\beta$-D-glucopyranoside, $\quad \mathrm{pNP}-\beta$-D-galactopyranoside, pNP- $\alpha$-D-glucopyranoside, bis-pNP-phosphate, bis-pNPphenyl-phosphonate, bis-pNP-phosphoryl-choline, 2-deoxythymidine-2'-pNP-phosphate, L-alanine-p-nitroanilide (pNA), $\gamma$-L-glutamate-pNA and L-proline-pNA are hydrolysed but not $\mathrm{pNP}-\beta$-D-xylopyranoside or $\mathrm{pNP}-\beta$-D-glucuronide. Major cellular fatty acids are iso- $\mathrm{C}_{15: 0}$, iso- $\mathrm{C}_{17: 0} 3-\mathrm{OH}$ and summed feature 4 (iso- $\mathrm{C}_{15: 0} 2-\mathrm{OH}$ and/or $\mathrm{C}_{16: 1} \omega 7 c / t$ ). The only menaquinone is MK-6. The major polar lipids are diphosphatidylglycerol, phosphatidylinositol, a characteristic unknown phospholipid, and unknown polar lipids and glycolipids.

The type strain is $\mathrm{R}^{2} 6^{\mathrm{T}}\left(=\mathrm{CCUG} 60038^{\mathrm{T}}=\mathrm{CCM} 7804^{\mathrm{T}}\right.$ ), isolated from the midgut of Anopheles gambiae G3, originating from McCarthy Island, The Gambia, and deposited by Dr William Collins at Malaria Research Reference Resource Centre.

\section{References}

Bernardet, J.-F., Hugo, C. \& Bruun, B. (2006). The genera Chryseobacterium and Elizabethkingia. In The Prokaryotes: a Handbook on the Biology of Bacteria, 3rd edn, vol. 7, pp. 638-676. Edited by M. Dworkin, S. Falkow, E. Rosenberg, K. H. Schleifer \& E. Stackebrandt. New York: Springer.

Collins, M. D. \& Jones, D. (1980). Lipids in the classification and identification of coryneform bacteria containing peptidoglycans based on 2,4-diaminobutyric acid. J Appl Bacteriol 48, 459-470.

Collins, M. D., Pirouz, T., Goodfellow, M. \& Minnikin, D. E. (1977). Distribution of menaquinones in actinomycetes and corynebacteria. J Gen Microbiol 100, 221-230.

Dong, Y., Manfredini, F. \& Dimopoulos, G. (2009). Implication of the mosquito midgut microbiota in the defense against malaria parasites. PLoS Pathog 5, e1000423.

Gerhardt, P., Murray, R. G. E., Wood, W. A. \& Krieg, N. R. (editors) (1994). Methods for General and Molecular Bacteriology. Washington, DC: American Society for Microbiology.

Groth, I., Schumann, P., Weiss, N., Martin, K. \& Rainey, F. A. (1996). Agrococcus jenensis gen. nov., sp. nov., a new genus of actinomycetes with diaminobutyric acid in the cell wall. Int J Syst Bacteriol 46, 234239.

Kajla, M. K., Andreeva, O., Gilbreath, T. M., III \& Paskewitz, S. M. (2010). Characterization of expression, activity and role in antibacterial immunity of Anopheles gambiae lysozyme c-1. Comp Biochem Physiol B Biochem Mol Biol 155, 201-209.

Kämpfer, P. \& Kroppenstedt, R. M. (1996). Numerical analysis of fatty acid patterns of coryneform bacteria and related taxa. Can $J$ Microbiol 42, 989-1005.

Kämpfer, P., Steiof, M. \& Dott, W. (1991). Microbiological characterization of a fuel-oil contaminated site including numerical identification of heterotrophic water and soil bacteria. Microb Ecol 21, 227-251.

Kämpfer, P., Dreyer, U., Neef, A., Dott, W. \& Busse, H.-J. (2003). Chryseobacterium defluvii sp. nov., isolated from wastewater. Int J Syst Evol Microbiol 53, 93-97.

Kämpfer, P., Arun, A. B., Young, C.-C., Chen, W.-M., Sridhar, K. R. \& Rekha, P. D. (2010). Chryseobacterium arthrosphaerae sp. nov., isolated from the faeces of the pill millipede Arthrosphaera magna Attems. Int J Syst Evol Microbiol 60, 1765-1769.

Kim, K. K., Kim, M. K., Lim, J. H., Park, H. Y. \& Lee, S.-T. (2005). Transfer of Chryseobacterium meningosepticum and Chryseobacterium miricola to Elizabethkingia gen. nov. as Elizabethkingia meningoseptica comb. nov. and Elizabethkingia miricola comb. nov. Int J Syst Evol Microbiol 55, 1287-1293.

Lane, D. J. (1991). 16S/23S rRNA sequencing. In Nucleic Acid Techniques in Bacterial Systematics, pp. 115-175. Edited by E. Stackebrandt \& M. Goodfellow. Chichester: Wiley.

Lindh, J. M., Borg-Karlson, A.-K. \& Faye, I. (2008). Transstadial and horizontal transfer of bacteria within a colony of Anopheles gambiae (Diptera: Culicidae) and oviposition response to bacteria-containing water. Acta Trop 107, 242-250.

Ludwig, W., Strunk, O., Westram, R., Richter, L., Meier, H., Yadhukumar, Buchner, A., Lai, T., Steppi, S. \& other authors (2004). ARB: a software environment for sequence data. Nucleic Acids Res 32, 1363-1371.

Minnikin, D. E., Collins, M. D. \& Goodfellow, M. (1979). Fatty acid and polar lipid composition in the classification of Cellulomonas, Oerskovia and related taxa. J Appl Bacteriol 47, 87-95.

Olsen, G. J., Matsuda, H., Hagstrom, R. \& Overbeek, R. (1994). fastDNAmL: a tool for construction of phylogenetic trees of DNA 
sequences using maximum likelihood. Comput Appl Biosci 10, 41-48.

Pruesse, E., Quast, C., Knittel, K., Fuchs, B. M., Ludwig, W., Peplies, J. \& Glöckner, F. O. (2007). SILVA: a comprehensive online resource for quality checked and aligned ribosomal RNA sequence data compatible with ARB. Nucleic Acids Res 35, 7188-7196.

Reichenbach, H. (1992). The order Cytophagales. In The Prokaryotes, 2nd edn, vol. 4, pp. 3631-3675. Edited by A. Balows, H. G. Trüper, M. Dworkin, W. Harder \& K. H. Schleifer. New York: Springer.

Smibert, R. M. \& Krieg, N. R. (1994). Phenotypic characterization. In Methods for General and Molecular Bacteriology, pp. 607-654. Edited by P. Gerhardt, R. G. E. Murray, W. A. Wood \& N. R. Krieg. Washington, DC: American Society for Microbiology.
Versalovic, J., Schneider, M., de Bruijn, F. J. \& Lupski, J. R. (1994). Genomic fingerprinting of bacteria using repetitive sequence-based polymerase chain reaction. Methods Mol Cell Biol 5, 25-40.

Welsh, J. \& McClelland, M. (1990). Fingerprinting genomes using PCR with arbitrary primers. Nucleic Acids Res 18, 7213-7218.

Williams, J. G. K., Kubelik, A. R., Livak, K. J., Rafalski, J. A. \& Tingey, S. V. (1990). DNA polymorphisms amplified by arbitrary primers are useful as genetic markers. Nucleic Acids Res 18, 6531-6535.

Ziemke, F., Brettar, I. \& Höfle, M. G. (1997). Stability and diversity of the genetic structure of a Shewanella putrefaciens population in the water column of the central Baltic. Aquat Microb Ecol 13, 63-74.

Ziemke, F., Höfle, M. G., Lalucat, J. \& Rosselló-Mora, R. (1998). Reclassification of Shewanella putrefaciens Owen's genomic group II as Shewanella baltica sp. nov. Int J Syst Bacteriol 48, 179-186. 